\title{
Pengaruh E-servicescape Online Marketplace Shopee pada Perceived Value dan Kepuasan Pelanggan, serta Dampaknya terhadap Loyalitas Pelanggan
}

\author{
Marsha Karina \\ Manajemen, Universitas Airlangga, Indonesia \\ Korespondensi penulis: karina.marsha1994@gmail.com
}

\begin{abstract}
Online marketplace business competition is getting tougher, so customer loyalty is becoming an increasingly important factor for companies. Shopee is one of the increasingly popular online marketplace business in Indonesia. Customer loyalty can be rised through increasing the number of transactions and visits on the Shopee website. E-servicescapes are all elements that companies use to deliver digital services to consumers. The elements of e-servicescapes include aesthetic appeals, layout and functionality, and financial security. The level of customer satisfaction and perceived value of e-servicescapes can increase customer loyalty which have an impact for increasing the number of visits to Shopee's website. The purpose of this study is to determine the e-servicescape elements that most influence the satisfaction and perceived value of Shopee website users. This study used a quantitative approach with primary data derived from Shopee website users. An important contribution of this research is the guideline to improve the quality of e-servicescapes, so that the company is able to get a higher level of customer loyalty. The results of this study indicate that e-servicescapes affect the perceived value and customer satisfaction that can encourage the formation of their loyalty. Other findings show that Shopee has financial security as the best e-servicescape aspect. However, Shopee still needs improvements in the aspects of layout and functionality, because these aspects get the lowest ratings from Shopee website users.
\end{abstract}

Keywords: E-servicescape; Perceived value; Satisfaction; Loyalty; Online marketplace.

\begin{abstract}
Abstrak. Persaingan bisnis online marketplace semakin ketat, sehingga loyalitas pelanggan menjadi faktor yang semakin penting bagi perusahaan. Shopee merupakan salah satu bisnis online marketplace yang semakin dikenal di Indonesia. Meningkatkan loyalitas pelanggan dapat dilakukan melalui peningkatan jumlah transaksi dan kunjungan di website Shopee. E-servicescape adalah seluruh elemen yang digunakan perusahaan untuk menyampaikan layanan digital kepada konsumen. Elemen-elemen e-servicescape meliputi aesthetic appeal, layout and functionality, dan financial security. Tingkat kepuasan dan perceived value konsumen terhadap e-servicescape dapat meningkatkan loyalitas pelanggan yang berdampak pada meningkatnya jumlah kunjungan pada website Shopee. Tujuan penelitian ini adalah untuk mengetahui elemen-elemen $e$ servicescape yang paling berpengaruh pada kepuasan dan perceived value pengguna
\end{abstract}


website Shopee. Penelitian ini menggunakan pendekatan kuantitatif dengan data primer yang berasal dari pengguna website Shopee. Kontribusi penting penelitian ini adalah pedoman peningkatan kualitas e-servicescape, sehingga perusahaan mampu mendapatkan tingkat loyalitas pelanggan lebih tinggi. Hasil penelitian ini menunjukkan bahwa $e$ servicescape berpengaruh pada perceived value dan kepuasan pelanggan yang dapat mendorong terbentuknya loyalitas mereka. Temuan lain menunjukkan bahwa Shopee memiliki financial security sebagai aspek e-servicescape terbaik. Namun, Shopee masih membutuhkan perbaikan pada aspek layout and functionality, karena aspek tersebut mendapatkan penilaian terendah dari para pengguna website Shopee.

Kata Kunci: E-servicescape; Nilai yang dipersepsikan; Kepuasan; Loyalitas; Online marketplace.

Article Info:

Received: October 21, 2019 Accepted: November 8, 2019 Available Online: December 18, 2019

DOI: http://dx.doi.org/10.30588/jmp.v9i1.534

\section{LATAR BELAKANG}

Dengan tingginya perkembangan e-commerce di Indonesia, persaingan para pelaku e-commerce menjadi semakin ketat. Para pelaku bisnis e-commerce memiliki harapan dan keinginan mencapai tingkat layanan e-commerce terpercaya dan mendapatkan transaksi sebanyak mungkin. Tidak hanya ingin menjadi yang terpercaya, setiap pelaku e-commerce juga ingin memiliki tingkat loyalitas pelanggan yang tinggi (Lin \& Sun, 2009). Shopee, salah satu bisnis online marketplace di Indonesia, juga ingin berkembang ke arah tersebut, Sama dengan yang ingin dicapai pelaku e-commerce lain pada umumnya (Setyowati, 2018).

Shopee memiliki aplikasi online marketplace untuk melakukan jual beli produk dengan lebih mudah dan cepat. Shopee menawarkan berbagai macam produk mulai dari produk fashion hingga kebutuhan sehari-hari. Shopee mulai masuk ke pasar Indonesia pada akhir bulan Mei 2015 dan baru mulai beroperasi pada akhir Juni 2015 (Setyowati, 2018). Walaupun baru memasuki pasar Indonesia pada tahun 2015, Shopee berkembang cukup pesat. Hal itu terbukti dari total transaksi Shopee sepanjang kuartal ketiga tahun 2018 yang tercatat sebesar US\$2,7 miliar atau sekitar Rp39,4 triliun. Nilai tersebut tumbuh 152,7\% dibandingkan periode yang sama tahun 2017 yang mencapai US\$1,1 miliar (Setyowati, 2018). Jumlah pengguna layanan Shopee bertumbuh sekitar 150\% dibandingkan kuartal ketiga tahun 2017. Di Indonesia, aplikasi Shopee telah diunduh sekitar 74 juta kali, baik di Google PlayStore maupun AppStore (Setyowati, 2018).

Berdasarkan riset yang dilakukan oleh iPrice Group (2018), Shopee menjadi aplikasi online marketplace nomor satu di Indonesia pada kuartal keempat tahun 2018. Pencapaian tersebut dipicu oleh beberapa keunggulan dan strategi pemasaran yang baik (misalnya gratis biaya pengiriman), baik di PlayStore maupun AppStore. Namun, kunjungan website Shopee masih menduduki posisi nomor ketiga di bawah Tokopedia dan Bukalapak (iPrice Group, 2018), sehingga Shopee perlu berupaya untuk meningkatkan jumlah transaksi dan kunjungan ke websitenya. Penyebab kurangnya jumlah kunjungan website Shopee dapat dilihat dari perilaku pengguna websitenya. Berdasarkan analisis kinerja website oleh SimiliarWeb (2018), bounce rate Shopee cukup tinggi, 
yaitu $42,48 \%$. Bounce rate adalah jumlah pengguna yang langsung meninggalkan situs setelah membuka satu halaman. Berdasarkan analisis SimiliarWeb (2018) tersebut, halaman yang paling banyak dikunjungi pada website Shopee adalah halaman utama $(69,99 \%)$, sehingga indikator tersebut dapat diartikan banyaknya pengguna yang meninggalkan situs Shopee setelah membuka halaman utamanya saja.

Berdasarkan data tersebut, Shopee memiliki kekurangan dalam menampilkan visual dan fitur yang membuat penggunanya memutuskan untuk keluar dari situs Shopee. Selain itu, fitur keywords yang kurang tepat, sehingga produk yang ditampilkan tidak sesuai dengan yang dicari pengguna. Segala kemungkinan tersebut termasuk ke dalam permasalahan e-servicescape, sehingga Shopee perlu mengetahui bagaimana tingkat kepuasan pengguna dan perceived value mereka terhadap e-servicescape Shopee. Setelah mengetahui kedua faktor tersebut, pengembang website Shopee dapat mengetahui permasalahan e-servicescape situs Shopee. Dengan perbaikan permasalahan tersebut, Shopee dapat meningkatkan jumlah kunjungan dan pembelanjaannya melalui website yang dapat meningkatkan loyalitas mereka juga.

Servicescape adalah sebuah lingkungan terjadinya penyampaian layanan. Dalam lingkungan digital (online), maka lingkungan tersebut dikenal dengan e-servicescape (Harris \& Goode, 2010), sehingga $e$-servicescape merupakan lingkungan terjadinya $e$ service. Tankovic dan Benazic (2018) menyebutkan ada tiga elemen yang termasuk dalam lingkup e-servicescape, yaitu aesthetic appeal, layout and functionality, dan financial security. Ketiga elemen e-servicescape tersebut sangat mempengaruhi tingkat perceived values dan kepuasan konsumen (Tankovic \& Benazic, 2018; Ha \& Stoel, 2012). Kepuasan pelanggan merupakan cerminan perceived value yang dirasakan oleh konsumen. Jika value yang dirasakan jauh dari harapan, maka mereka akan kecewa. Sebaliknya, jika hal itu sesuai dengan harapan, maka pelanggan akan puas. Jika value melebihi harapan mereka, maka pelanggan akan sangat puas (Kotler \& Keller, 2016).

Menurut Tankovic dan Benazic (2018) dan Ha dan Stoel (2012), perceived values dan kepuasan pelanggan dapat membentuk loyalitas mereka. Loyalitas pelanggan dapat dipahami sebagai sebuah proses pembelian yang didasarkan pada preferensi, sikap, dan kebiasaan mereka terhadap satu atau lebih merek yang diekspresikan dalam jangka waktu tertentu, yaitu loyalitas dipandang sebagai hasil dari kepuasan pelanggan dan memberikan nilai unggul pada layanan dan produk yang berkualitas terbaik (Yang \& Peterson, 2004). Tujuan penelitian ini adalah untuk mengetahui elemen-elemen $e$ servicescape yang paling berpengaruh pada nilai yang dirasakan dan kepuasan pengguna website Shopee, serta loyalitas mereka. Penelitian ini memberikan kontribusi pemahaman terhadap pengembangan online marketplace, khususnya Shopee, agar dapat memperbaiki dan meningkatkan kualitas e-servicescape untuk mendapatkan tingkat loyalitas pelanggan yang lebih tinggi.

\section{KAJIAN TEORITIS}

\section{E-Servicescape}

Sebuah lingkungan di mana terjadi penyampaian layanan disebut dengan servicescape. Dalam lingkungan digital (online), maka lingkungan tersebut dinamakan $e$ servicescape (Harris \& Goode, 2010). E-servicescape merupakan lingkungan terjadinya e-service. Menurut Tankovic dan Benazic (2018), ada tiga komponen yang termasuk 
dalam lingkup e-servicescape, yaitu aesthetic appeal, layout and functionality, dan financial security. Ketiga komponen e-servicescape tersebut terdiri atas beberapa aspek. Aesthetic appeal adalah aspek kondisi lingkungan website dan sejauh mana konsumen mengartikan servicescape secara menarik atau memikat dan mencakup disain visual tampilan marketplace, originalitas, dan unsur entertainment (Harris \& Goode, 2010). Layout and functionality adalah pengaturan, pengorganisasian, struktur, dan kemampuan website beradaptasi serta sejauh mana faktor tersebut memfasilitasi hingga tujuan layanan terpenuhi yang meliputi elemen nilai guna, kesesuaian informasi, interaksi, dan customization (Harris \& Goode, 2010). Financial security adalah keamanan dan kemudahan dalam pembayaran dan sejauh mana pengguna merasakan proses pembayaran dan kebijakan umum website dapat terjamin dan aman (Harris \& Goode, 2010; Tankovic \& Benazic, 2018).

\section{Aesthetic Appeal}

Online aesthetic appeal mengacu pada kondisi lingkungan website dan sejauh mana konsumen mengartikan servicescape sebagai menarik atau memikat (Harris \& Goode, 2010). Konteks dan tampilan grafik sebuah halaman dapat memberikan dampak kepada pengguna. Harris dan Goode (2010) mengungkapkan beberapa aspek yang harus diperhatikan dalam aesthetic appeal, yaitu penggunaan background images yang sesuai; typography (bentuk dan jenis font) yang konsisten; penggunaan warna pada website; dan emosi yang ditampilkan melalui warna disain yang modern. Pengguna website akan menilai, mengevaluasi, dan memberikan kepercayaan terhadap lingkungan virtual yang memiliki aesthetic appeal yang baik. Aesthetic appeal akan menggiring pengguna website memiliki pengalaman berbelanja yang memuaskan dan akan menuntun mereka pada terbentuknya loyalitas (Harris \& Goode, 2010).

Menurut Shun dan Xu (2011), ada tiga hal yang harus dipahami tentang aesthetic appeal sebuah website. Pertama, estetika adalah persepsi holistik mengenai prinsip disain dan obyek individu. Konstruksi dan persepsi obyek apa pun melibatkan elemen disain tertentu (misalnya bentuk dan warna) dan prinsip (misalnya kesatuan, kontras, keseimbangan, dan proporsi). Berfokus hanya pada sebuah obyek tampilan secara individual dan mengabaikan hubungannya dengan obyek lain pada interface akan dapat mengakibatkan kegagalan disain. Kedua, estetika terkait erat dengan perhatian dan pemahaman. Estetika antarmuka menarik perhatian pengguna dan membuat mereka terlibat dan tenggelam dalam suatu kegiatan penelusuran. Selain itu, estetika melibatkan proses kognitif, yaitu pengguna mengklarifikasi, mengintensifkan, dan menafsirkan peristiwa dalam lingkungan visual. Estetika website juga dapat secara signifikan mempengaruhi pengaruh dan emosi orang (Shun \& Xu, 2011).

Wells, Valacich, dan Hess (2011) mengungkapkan dua atribut yang disampaikan melalui sebuah website, yaitu atribut produk intrinsik (seperti fitur produk tertulis, gambar, dan pengalaman produk virtual), dan atribut terkait produk ekstrinsik (seperti atribut harga, merek, dan kualitas website). Seperti halnya toko yang memiliki perabotan dan dekorasi yang bagus, website memiliki atribut (misalnya daya tarik visual, kemampuan navigasi, keamanan, waktu respon, dan lain-lain) yang dapat mempengaruhi persepsi kualitas produk. Atribut kualitas website ini dapat berfungsi sebagai sinyal dan mempengaruhi konsumen, terlepas dari atribut produk intrinsik yang disampaikan dalam website. Menurut Harris dan Goode (2010), ketika pengguna merasa menyukai disain visual sebuah e-commerce, mereka merasa disain tersebut terlihat atraktif dan 
membuatnya antusias dalam berbelanja, sehingga aesthetic appeal pada e-commerce tersebut berhasil mempengaruhi perceived value pengguna.

Shun dan $\mathrm{Xu}$ (2011) menyebutkan bahwa disain visual pada website yang menarik memiliki efek langsung terhadap nilai yang dirasakan oleh pengguna website dengan memasukkan unsur afektif. Hal ini disebabkan pengguna website dapat langsung menilai tingkat kemenarikan sebuah website secara cepat dengan menilai tampilan visualnya. Mengingat kualitas website menjadi salah satu indikator penilaian konsumen, jika konsumen percaya bahwa website berkualitas tinggi membutuhkan biaya pengolahan yang cukup tinggi dan keahlian yang signifikan, maka website berkualitas tinggi tersebut sangat mempengaruhi persepsi kualitas produk, karena mereka memahami bahwa hanya penjual berkualitas tinggi yang mampu melakukan investasi seperti itu (Wells et al., 2011). Dari penjelasan tersebut, hipotesis pertama dirumuskan sebagai berikut:

\section{H1: Persepsi atas aesthetic appeal berpengaruh positif pada perceived value peng- guna website Shopee.}

Tampilan website (misalnya cara menampilkan foto produk, warna yang digunakan, dan jenis tulisan) berpengaruh positif terhadap nilai kesenangan selama berbelanja di sebuah website (Shun \& Xu, 2011). Ketika konsumen merasakan kesenangan pada tampilan visual website, maka konsumen akan mudah merasakan kepuasan terhadap elemen website yang lain, seperti layout and functionality (Shun \& Xu, 2011). Elemen visual website juga harus cukup jelas dan terorganisasi dengan baik, sehingga konsumen akan mudah menggunakan website. Ketika konsumen merasa lebih mudah menggunakan website, maka mereka lebih mudah untuk merasa puas dengan website tersebut (Guo, Ling, \& Liu, 2012). Hal ini dikarenakan konsumen akan mudah mengaitkan nilai kegunaan website dan tampilan visualnya (Shun \& Xu, 2011). Dari penjabaran tersebut, hipotesis kedua dirumuskan sebagai berikut:

\section{H2: Persepsi atas aesthetic appeal berpengaruh positif pada kepuasan pengguna website Shopee.}

\section{Layout and Functionality}

Berbeda dengan aesthetic appeal, tata letak pada tampilan online mengacu pada pengaturan, pengorganisasian, struktur, dan kemampuan website beradaptasi. Sementara itu, fungsionalitas mengacu pada sejauh mana faktor tersebut memfasilitasi hingga tujuan layanan terpenuhi. Fungsionalitas dan kegunaan sebuah website menjadi faktor penting bagi konsumen untuk mengevaluasi keefektifan website bekerja (Harris \& Goode, 2010). Contohnya, pembeli online akan merasa lebih aman, jika ia bisa berinteraksi dengan penjual melalui fitur chat dan menjadikan aspek tersebut sebagai salah satu faktor penting dalam e-servicescape.

Tindakan mencari jalan di website umumnya disebut navigasi. Hoffman dan Novak (1996) mendefinisikan navigasi sebagai proses gerakan mandiri melalui lingkungan yang diperantarai komputer. Di dalam website, pemasar menggunakan tautan teks dan ikon sebagai isyarat untuk membantu navigasi konsumen (Hoffman \& Novak, 1996). Isyarat navigasi ini dapat diklasifikasikan menurut tipologi (Baker, 1986). Eroglu, Machleit, dan Davis (2001) mengklasifikasikannya sebagai isyarat disain yang relevan dengan tugas dan fungsional. Salah satu jenis isyarat navigasi di website adalah 
tombol next dan previous links tautan halaman. Dengan isyarat ini, pemasar dapat mengontrol urutan navigasi website, sehingga memungkinkan pemasar memiliki kontrol yang kuat atas informasi yang diterima oleh konsumen. Di luar tombol next dan previous, banyak pemasar menggunakan kolom navigasi pada halaman beranda dan halaman website berikutnya sebagai isyarat navigasi (Rajani \& Rosenberg, 1999).

Kolom navigasi adalah sekumpulan tautan yang tercantum pada setiap halaman website yang dapat diklik oleh pengguna untuk berpindah ke bagian yang diinginkan dan melihat halaman tersebut (Rodriguez et al., 1997). Dengan isyarat navigasi jenis ini, pemasar menentukan bagian sebelumnya dan halaman penting yang mereka inginkan dapat dilihat oleh konsumen, seperti informasi produk, informasi pengiriman, dan sebagainya. Untuk membantu navigasi lebih lanjut, beberapa pemasar menambahkan tautan indeks situs ke bilah navigasi mereka. Indeks situs adalah halaman website yang mencantumkan dan menyediakan tautan ke semua atau sebagian besar halaman website (Rodriguez et al., 1997). Dengan indeks website, konsumen lebih mudah menemukan informasi yang lebih spesifik.

Luo, Sulin, dan Han (2012) mengungkapkan bahwa tata letak website memainkan peran penting agar pelanggan dapat menemukan informasi online dengan lebih cepat. Kemudahan akses untuk mendapatkan sebuah informasi akan meningkatkan nilai persepsi pelanggan. Dampak negatif lebih parah akan dirasakan pada kasus disain website yang buruk, yaitu pelanggan tidak mudah menemukan informasi. Hal itu akan menurunkan nilai kepuasan pelanggan. Di sisi lain, website yang dirancang dengan baik dapat memfasilitasi pencarian informasi dan mengurangi kemungkinan ketidaksesuaian. Dengan informasi yang disediakan oleh retailer, pelanggan akan sulit mencari kesalahan saat terjadi ketidaksesuaian preferensi yang diharapkan pelanggan dengan produk yang diterima. Konsumen cenderung menghubungkan ketidaksesuaian dengan kesalahan interpretasinya (Westbrook, 1987). Oleh karena itu, website yang dirancang dengan tepat memungkinkan konsumen lebih mudah menemukan informasi kualitas produk yang diperlukan dan mengurangi dampak ketidakpastian produk, serta visibilitas retailer yang rendah pada kepuasan pasca pembelian. Selain itu, disain website yang baik harus memiliki nilai lebih bagi konsumen agar lebih mudah mencari produk dan membantu retailer dengan visibilitas rendah.

Luo et al. (2012) mengungkapkan bahwa website yang dirancang dengan baik dapat memfasilitasi pencarian informasi dan mengurangi kemungkinan ketidaksesuaian. Dengan memberikan informasi yang cukup, maka pengguna akan merasakan nilai penghematan waktu saat mencari suatu produk. Alur penyajian halaman website yang jelas, adanya kolom navigasi yang berisi tautan yang membantu pengguna, dan indeks website yang lengkap akan membuat pengguna merasakan nilai lebih dari website tersebut (Dailey, 2004). Wu, Chen K., Chen P., dan Cheng (2014) mengungkapkan bahwa semakin rendah usaha yang perlu dikeluarkan oleh konsumen untuk mencari sebuah produk dalam suatu website, semakin tinggi nilai yang dirasakan oleh mereka. Informasi yang cukup dan cepat ditemukan akan membentuk penilaian pelanggan terhadap brand suatu website. Kesadaran brand membuat konsumen lebih efisien menggunakan website untuk belanja online dan meningkatkan perbedaan waktu dan usaha yang harus dikeluarkan dibandingkan dengan situs lain dan hanya kembali ke situs yang mereka sukai, yaitu pembeli online dapat melakukan penelusuran dan tindakan pembelian di tingkat tercepat. 
Sama dengan pendapat Luo et al. (2012) dan Dailey (2004), Harris dan Goode (2010) mengungkapkan bahwa pengguna akan merasa e-commerce mudah digunakan, ketika navigasi yang diberikan di dalam aplikasi jelas, sehingga mereka tidak perlu mengeluarkan usaha yang besar untuk menggunakan website dan mampu memberikan informasi yang lengkap, sehingga mereka tidak perlu mengeluarkan biaya pencarian informasi yang tinggi. Dengan demikian, Layout and Functionality pada e-commerce berhasil mempengaruhi perceived value pembeli, sehingga hipotesis ketiga dirumuskan berikut ini:

\section{H3: Persepsi atas layout and functionality berpengaruh positif pada perceived value pengguna website Shopee.}

Wang, Tang, dan Tang (2001) menyebutkan bahwa ada beberapa aspek yang mempengaruhi kepuasan pelanggan terhadap fungsionalitas sebuah website. Informasi tentang produk secara terperinci, pengelompokan produk, dan kata kunci pencarian yang sesuai akan membuat pengguna puas dengan rekomendasi produk yang ditampilkan oleh website, karena sesuai dengan produk yang mereka cari. Pemberian informasi yang rinci juga akan mengurangi ketidakpuasan pelanggan saat produk yang didapat berbeda dengan apa yang diharapkan, karena pengguna akan berpikir ada kesalahan penafsiran informasi yang disajikan oleh websitenya (Luo et al., 2012).

Adanya fitur pesan (chat) akan sangat membantu meningkatkan kepuasan pengguna (Harris \& Goode, 2010), baik fitur pesan kepada layanan pelanggan maupun kepada penjual. Website yang memiliki fitur chat akan sangat membantu pelanggan, ketika mereka mengalami suatu kendala. Layanan pelanggan yang solutif dan ramah, serta fitur chat yang lengkap dapat membantu ketika pelanggan bertanya kepada penjual, sehingga hal itu membuat pengguna merasa puas (Ha \& Stoel, 2012). Dari uraian tersebut, hipotesis keempat dirumuskan sebagai berikut:

\section{H4: Persepsi atas layout and functionality berpengaruh positif pada kepuasan pengguna website Shopee.}

\section{Financial Security}

Keamanan finansial pada layanan online mengacu pada sejauh mana konsumen merasakan proses pembayaran dan kebijakan umum website dapat terjamin dan aman. Keamanan dan kemudahan pembayaran pada suatu website dapat menjadi faktor bagi konsumen untuk mengevaluasi sebuahnya (Harris \& Goode, 2010). Keamanan finansial mengacu pada persepsi pelanggan terhadap prosedur pembayaran dan kebijakan umum website (Adiwijaya, Thomas, Agustinus, \& Endo, 2016). Kemudahan pembayaran adalah salah satu contoh keamanan finansial yang dapat menciptakan kinerja website berdasarkan evaluasi pelanggan.

Privasi dan keamanan adalah kriteria evaluasi utama dalam layanan online (Zeithaml, Parasuraman, \& Malhotra, 2002). Dua kriteria ini terkait satu sama lain. Privasi melibatkan perlindungan informasi pribadi - tidak berbagi informasi pribadi yang dikumpulkan tentang konsumen dengan website lain (seperti dalam daftar penjualan), melindungi anonimitas, dan memberikan persetujuan (Friedman, Kahn, \& Howe, 2000). Di sisi lain, keamanan dilibatkan untuk melindungi pengguna dari risiko penipuan dan kerugian finansial yang berasal dari penggunaan kartu kredit mereka atau informasi keuangan lainnya. Persepsi risiko keamanan telah terbukti berdampak kuat 
pada sikap terhadap penggunaan layanan keuangan online (Montoya-Weiss, Voss, \& Grewal, 2003).

Zeithaml et al. (2002) mengungkapkan beberapa hal yang mendasari penilaian pelanggan terhadap keamanan finansial, antara lain metode pembayaran dan jaminan keamanan yang ditawarkan oleh website terkait data pribadi pelanggan (termasuk data pembayaran). Ketika pelanggan diminta memasukkan berbagai data untuk registrasi, mereka melakukan pembayaran dengan mudah dan menerima order tracking, serta garansi keamanan yang baik, maka pelanggan akan merasa aman. Hal tersebut sejalan dengan pemikiran Harris dan Goode (2010) yang menyatakan ketika pengguna merasa suatu $e$-commerce memberikan jaminan keamanan terhadap data pribadi dan pembayaran, serta memberikan kemudahan dalam pembayaran, maka finansial security pada $e$ commerce tersebut berhasil mempengaruhi perceived value pembeli. Dari uraian tersebut, hipotesis kelima dirumuskan sebagai berikut:

\section{H5: Persepsi atas financial security berpengaruh positif pada perceived value pengguna website Shopee.}

Menurut Guo et al (2012), ketika pengguna merasa puas dengan berbagai pilihan pembayaran yang disediakan oleh e-commerce, maka hal itu dapat dikatakan bahwa financial security pada e-commerce tersebut berhasil mempengaruhi kepuasan pembeli. Wang et al. (2001) mengungkapkan hal serupa tentang kepuasan pelanggan terhadap sistem pembayaran yang ditawarkan oleh sebuah website. Proses transaksi yang jelas dan mudah akan membuat pelanggan merasa puas. Selain itu, rincian harga (termasuk ongkos kirim) yang ditampilkan secara jelas juga dapat meningkatkan kepuasan pelanggan, karena mereka akan merasa mengeluarkan sedikit usaha untuk melakukan transaksi pembayaran pada website tersebut. Dari uraian tersebut, hipotesis keenam dirumuskan sebagai berikut:

\section{H6: Persepsi atas financial security berpengaruh positif pada kepuasan pengguna website Shopee.}

\section{Perceived Value dan Kepuasan Pelanggan}

Ketiga elemen e-servicescape sangat mempengaruhi tingkat perceived value dan kepuasan konsumen (Tankovic \& Benazic, 2018; Ha \& Stoel, 2012). Perceived value atau disebut juga customer perceived value adalah perbedaan antara pertimbangan dari segala benefit dan cost yang mereka harapkan dari satu produk dengan produk pembanding lainnya (Kotler \& Keller, 2016). Perceived value meliputi pengeluaran material maupun non-material, yaitu waktu yang dikorbankan, usaha, dan tekanan yang harus dihadapi pelanggan (Yang \& Peterson, 2004).

Kepuasan pelanggan adalah perasaan puas atau kecewa yang merupakan hasil dari upaya membandingkan kinerja yang dirasakan dari suatu produk atau jasa dengan ekspektasi mereka (Kotler \& Keller, 2016). Semakin positif nilai yang dirasakan pengguna website terhadap elemen e-servicescape, maka semakin tinggi pula tingkat kepuasan pelanggan tersebut. Pelanggan akan merasa puas ketika mereka merasa sedikit mengeluarkan usaha untuk mendapatkan fungsi optimal dari e-servicescape sebuah website (Wu et al., 2014). Penggunaan konsep customer perceived value tidak hanya menghasilkan pelanggan yang puas atau tidak puas, tetapi yang lebih penting lagi adalah adanya efek langsung pada niat dan loyalitas pelanggan. Dengan kata lain, 
semakin banyak manfaat yang ditawarkan oleh produk atau layanan, pelanggan merasa semakin puas, sehingga semakin tinggi peluang yang mengarah pada perilaku positif (Lin \& Sun, 2009). Dari uraian tersebut, hipotesis ketujuh dirumuskan berikut ini:

\section{H7: Perceived value berpengaruh positif pada kepuasan pengguna website Shopee.}

\section{Loyalitas Pelanggan}

Menurut Tankovic dan Benazic (2018) dan Ha dan Stoel (2012), perceived value dan kepuasan pelanggan dapat membentuk loyalitas pelanggan. Loyalitas pelanggan dapat diartikan sebagai proses pembelian yang didasarkan pada preferensi, sikap, dan kebiasaan terhadap satu atau lebih merek yang diekspresikan dalam jangka waktu tertentu, yaitu loyalitas dipandang sebagai hasil dari pelanggan yang puas dan memberikan nilai unggul atas layanan dan produk berkualitas terbaik (Yang \& Peterson, 2004). Loyalitas adalah hubungan kuat antara brand dan konsumen, sehingga pelanggan akan selalu mendukung dan menggunakan produk tersebut apa pun yang terjadi karena adanya perceived value dan kepuasan yang diperoleh konsumen (Kotler \& Keller, 2016).

Ketika pelanggan memberikan penilaian yang positif terhadap $e$-servicescape dan merasa mendapatkan banyak keuntungan dengan mengeluarkan tingkat usaha yang tidak tinggi, maka pelanggan akan kembali menggunakan website tersebut dan menjadikannya sebagai pilihan utama (Wang et al. 2001). Menurut Tankovic dan Benazic (2018), ketika pengguna merasa sebuah layanan e-commerce memberikan keuntungan ekonomis, menghemat waktu, dan aktifitas jual beli dapat dilakukan dengan mudah tanpa usaha yang besar, maka kondisi tersebut akan mendorong pengguna untuk merekomendasikannya kepada orang lain, sehingga perceived value atas e-commerce tersebut berhasil mempengaruhi loyalitas pengguna. Berdasarkan uraian tersebut, hipotesis kedelapan dirumuskan sebagai berikut:

\section{H8: Perceived value berpengaruh positif terhadap loyalitas pengguna website Shopee.}

Menurut Kottler dan Keller (2016), kepuasan akan muncul ketika apa yang disajikan oleh sebuah produk melebihi harapan yang dimiliki oleh pelanggan. Sebelum melakukan pemilihan e-commerce, pembeli telah melakukan terlebih dahulu pencarian informasi yang membentuk persepsi terhadap e-commerce tersebut. Ketika $e$-commerce berhasil memberikan kualitas e-servicescape melebihi informasi yang sudah dikumpulkan, maka pelanggan akan merasa puas dan menjadi loyal (Wu et al., 2014). Menurut Ha dan Stoel (2012), pengguna merasa puas atas kinerja e-commerce dengan tampilan visual, maka berbagai informasi yang disediakan dan banyaknya alternatif pembayaran pada e-commerce tersebut akan mendorong pengguna untuk merekomendasikannya kepada orang lain. Selanjutnya, nilai kepuasan atas layanan e-commerce tersebut dapat mempengaruhi loyalitas pengguna. Dari uraian tersebut, hipotesis kesembilan dirumuskan sebagai berikut:

\footnotetext{
H9: Kepuasan pelanggan berpengaruh positif terhadap loyalitas pengguna website Shopee.
} 
Dari paparan hubungan antarvariabel dan rumusan hipotesis tersebut di atas, maka model penelitian ini didisain seperti pada Gambar 1 berikut ini.

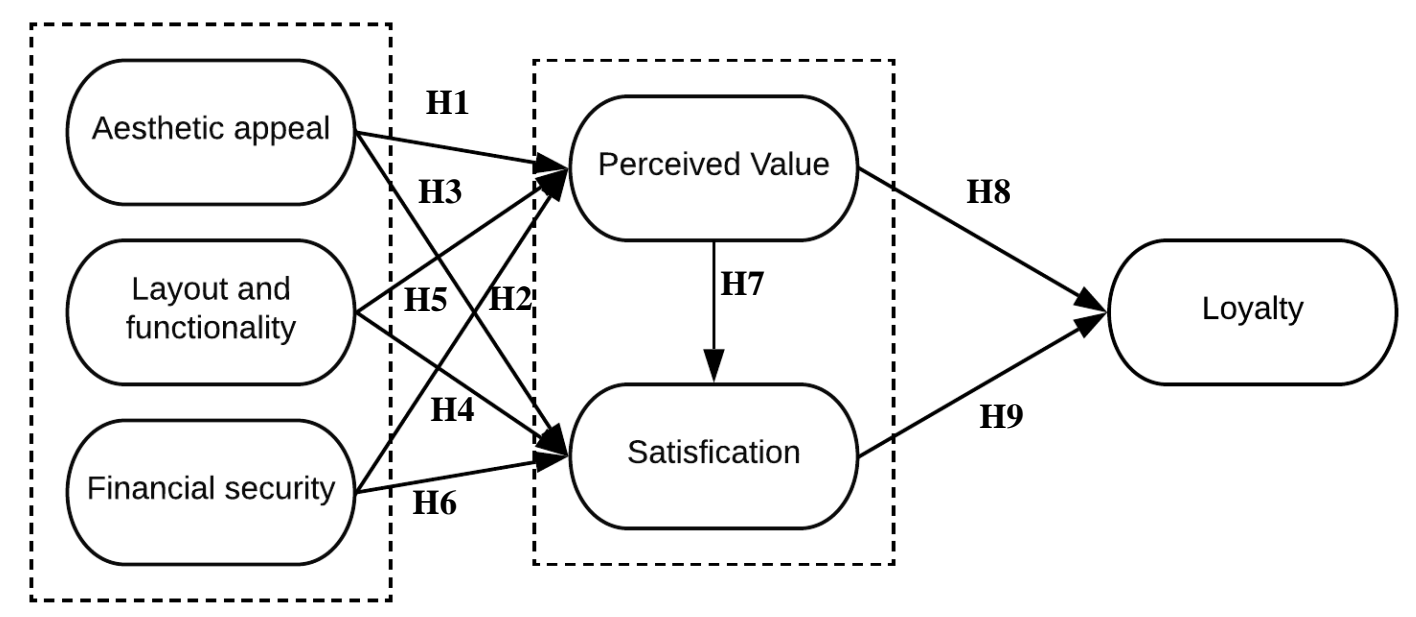

Gambar 1. Model Penelitian

\section{METODE PENELITIAN}

Penelitian ini merupakan penelitian eksplanatori yang dilakukan dengan pendekatan kuantitatif. Pemilihan pendekatan kuantitatif, karena data yang didapat dari instrumen penelitian berupa data numerik yang akan dianalisis menggunakan analisis statistik. Dalam penelitian ini, variabel yang dianalisis adalah pengaruh aesthetic appeal, layout and functionality, dan financial security terhadap perceived value dan kepuasan pelanggan yang menghasilkan loyalitas pelanggan.

Populasi pada penelitian ini adalah pengguna website Shopee di Indonesia yang berperan sebagai pembeli produk yang ditawarkannya. Sampel adalah sebuah himpunan atau bagian dari sebuah populasi (Zikmund, Babin, Carr, \& Griffin, 2013). Penelitian ini menentukan sampel dengan menggunakan metode non-random sampling dengan jenis purposive sampling. Menurut Maxwell (1996), purposive sampling adalah strategi pengaturan tertentu (orang atau peristiwa) yang dipilih secara sengaja untuk memberikan informasi penting dan tidak dapat diperoleh dari pilihan lain. Jumlah sampel yang digunakan sebanyak 200 orang responden dengan karakteristik sebagai berikut:

1. Responden telah menggunakan website Shopee sebagai pembeli minimal selama enam bulan terakhir, sehingga ia masih memahami update terakhir website Shopee.

2. Responden melakukan pembelian melalui website Shopee dengan minimal satu kali pembelian dalam enam bulan terakhir.

Metode pengumpulan data menggunakan metode Internet-Based Questionnaire Survey. Wu et al. (2014) menyarankan untuk menggunakan metode ini, karena ia menganggapnya lebih tepat untuk fokus pada interpretasi konsumen dalam kondisi alaminya. Kuesioner dibagikan melalui media sosial dan instant messenger (WhatsApp, Line, dan sebagainya). Instrumen penelitian berupa kuesioner didisain menggunakan open-ended questions dan fixed-questions. Open-ended quiestions digunakan untuk menanyakan data pribadi responden, sedangkan fixed-questions untuk menanyakan pendidikan, pekerjaan, dan frekuensi berbelanja. Fixed-questions yang digunakan untuk menguji 
variabel menggunakan skala Likert. Variabel yang diukur adalah aesthetic appeals, layout and functionality, financial security, customer loyalty, perceived value, dan customer satisfaction. Tabel 1 menunjukkan indikator yang digunakan untuk mengukur setiap variabel yang diteliti.

\section{Tabel 1. Indikator Pengukuran Variabel}

\begin{tabular}{|c|c|c|}
\hline Variabel & Indikator & Sumber \\
\hline $\begin{array}{l}\text { Aesthetic appeal } \\
\text { (X1) }\end{array}$ & $\begin{array}{l}\text { 1. Website menarik secara visual dan estetika. } \\
\text { 2. Tampilan visual website jelas dan mudah dipahami. } \\
\text { 3. Website memberikan sisi hiburan yang menarik. }\end{array}$ & $\begin{array}{l}\text { Harris dan } \\
\text { Goode (2010) }\end{array}$ \\
\hline $\begin{array}{l}\text { Layout and } \\
\text { functionality } \\
\text { (X2) }\end{array}$ & $\begin{array}{l}\text { 1. Ada alat bantu navigasi yang bermanfaat. } \\
\text { 2. Mudah untuk berpindah di antara halaman terkait dan } \\
\text { antara bagian yang berbeda. } \\
\text { 3. Memiliki fungsi kata kunci pencarian yang baik. } \\
\text { 4. Website memberikan rekomendasi produk yang sesuai } \\
\text { dengan kebutuhan. }\end{array}$ & $\begin{array}{l}\text { Harris dan } \\
\text { Goode (2010) }\end{array}$ \\
\hline $\begin{array}{l}\text { Financial Security } \\
\text { (X3) }\end{array}$ & $\begin{array}{l}\text { 1. Website memiliki prosedur pembayaran yang efisien. } \\
\text { 2. Fasilitas pembayaran dalam website mudah digunakan. } \\
\text { 3. Website memiliki sistem pembayaran yang aman. } \\
\text { 4. Website memberikan jaminan keamanan terhadap data } \\
\text { pribadi pengguna. }\end{array}$ & $\begin{array}{l}\text { Harris dan } \\
\text { Goode (2010) }\end{array}$ \\
\hline $\begin{array}{l}\text { Perceived Value } \\
\text { (Y1) }\end{array}$ & $\begin{array}{l}\text { 1. Website memberikan penghematan waktu pada } \\
\text { pengguna. } \\
\text { 2. Sangat mudah untuk berbelanja produk/layanan di } \\
\text { dalam website. } \\
\text { 3. Upaya yang harus dilakukan untuk membeli produk dari } \\
\text { website rendah. }\end{array}$ & $\begin{array}{l}\text { Wu et al. } \\
(2014)\end{array}$ \\
\hline $\begin{array}{l}\text { Customer Satisfaction } \\
\text { (Y2) }\end{array}$ & $\begin{array}{l}\text { 1. Sangat menyenangkan untuk berbelanja melalui } \\
\text { website. } \\
\text { 2. Pelayanan pada website ini sangat memuaskan. } \\
\text { 3. Adanya fasilitas fitur chat yang cepat dan sangat } \\
\text { membantu. }\end{array}$ & $\begin{array}{l}\text { Ha dan Stoel } \\
\text { (2012) }\end{array}$ \\
\hline $\begin{array}{l}\text { Customer Loyalty } \\
\text { (Z) }\end{array}$ & $\begin{array}{l}\text { 1. Pengguna akan merekomendasikan website ini kepada } \\
\text { orang lain. } \\
\text { 2. Pengguna jarang mempertimbangkan untuk beralih ke } \\
\text { website lain. } \\
\text { 3. Pengguna menggunakan website ini setiap kali berniat } \\
\text { melakukan pembelian produk. } \\
\text { 4. Ketika pengguna akan melakukan pembelian, website } \\
\text { ini adalah pilihan pertamanya. }\end{array}$ & $\begin{array}{l}\text { Tankovic dan } \\
\text { Benazic (2018) }\end{array}$ \\
\hline
\end{tabular}

Sumber: Artikel terkait.

Berdasarkan hipotesis yang diajukan dalam penelitian ini, maka teknik analisis data yang digunakan adalah structural equation model (SEM) yang diolah dengan bantuan software AMOS (Analysis of Moment Structures) versi 22. Confirmatory model digunakan karena model penelitian ini berasal dari teori yang sudah ada dan tujuan penelitian adalah untuk mengetahui adanya pengaruh (Bian, 2011). Penelitian ini dilakukan dengan dua tahap, yaitu:

1. Melakukan uji pengukuran model melalui pengujian validitas dan reliabilitas konstrak dari masing-masing indikator.

2. Menguji keseluruhan model dan hubungan antarvariabel yang ada dalam model penelitian sesuai dengan hipotesis yang dirumuskan, sehingga pengujian tersebut 
menghasilkan kesimpulan yang dapat digeneralisasikan dan menjawab rumusan masalah penelitian ini.

\section{HASIL DAN PEMBAHASAN}

\section{Confirmatory Model}

Pada tahap awal, penelitian ini dilakukan uji validitas dan reliabilitas masingmasing indikator untuk mengetahui adanya pengaruh indikator terhadap variabel. Menurut Bian (2011), indikator yang memiliki loading factor $>0,5$ dan reliability construct $>0,7$ maka indikatornya dianggap valid dan memiliki pengaruh pada variabel. Tabel 2 berikut ini adalah hasil uji covergent validity dan reliability construct menggunakan AMOS versi 22.

Tabel 2. Hasil Uji Covergent Validity dan Reliability Construct

\begin{tabular}{|c|c|c|c|c|}
\hline Variabel & Indikator & Loading Factor & Reliability Construct & Keterangan \\
\hline \multirow{3}{*}{ Aesthetic appeal } & A1 & 0,730 & \multirow{3}{*}{0,782} & Valid \\
\hline & $\mathrm{A} 2$ & 0,731 & & Valid \\
\hline & A3 & 0,753 & & Valid \\
\hline \multirow{4}{*}{ Layout \& functionality } & L1 & 0,784 & \multirow{4}{*}{0,873} & Valid \\
\hline & $\mathrm{L} 2$ & 0,607 & & Valid \\
\hline & L3 & 0,529 & & Valid \\
\hline & $\mathrm{L} 4$ & 0,674 & & Valid \\
\hline \multirow{4}{*}{ Financial security } & F1 & 0,689 & \multirow{4}{*}{0,897} & Valid \\
\hline & $\mathrm{F} 2$ & 0,919 & & Valid \\
\hline & F3 & 0,894 & & Valid \\
\hline & $\mathrm{F} 4$ & 0,523 & & Valid \\
\hline \multirow{3}{*}{ Perceived value } & PV1 & 0,609 & \multirow{3}{*}{0,744} & Valid \\
\hline & PV2 & 0,810 & & Valid \\
\hline & PV3 & 0,679 & & Valid \\
\hline \multirow{3}{*}{ Kepuasan pelanggan } & S1 & 0,720 & \multirow{3}{*}{0,773} & Valid \\
\hline & $\mathrm{S} 2$ & 0,736 & & Valid \\
\hline & S3 & 0,734 & & Valid \\
\hline \multirow{4}{*}{ Loyalitas pelanggan } & LY1 & 0,618 & \multirow{4}{*}{0,898} & Valid \\
\hline & LY2 & 0,626 & & Valid \\
\hline & LY3 & 0,902 & & Valid \\
\hline & LY4 & 0,903 & & Valid \\
\hline
\end{tabular}

Sumber: Hasil analisis data primer (2019).

Hasil pengujian pada Tabel 2 menunjukkan bahwa semua indikator pada setiap variabel memiliki nilai loading factor $>0,5$ dengan nilai construct reliability $>0,7$. Hasil ini menunjukkan bahwa seluruh indikator telah memenuhi convergent validity dan reliability construct.

\section{Structural Equation Model (SEM)}

Penelitian ini menggunakan AMOS versi 22 untuk mengolah model penelitian dengan teknik SEM. AMOS menggunakan pendekatan kovarian untuk menganalisis data pada model penelitian. Model persamaan struktural adalah tahapan untuk menguji kesesuaian model. Mengukur sebuah model dengan menggunakan AMOS mencakup lima tolok ukur yang dapat digunakan. Menurut Rosenbaum dan Spears (2009), tolok 
ukur yang digunakan untuk mengukur default model adalah RMSEA (Root Mean Square Error of Approximation), GFI (Goodness of Fit Index), CFI (Comparative Fit Index), TLI (Tucker-Lewis Index), dan CMIN/DF (Normed Chi-Square). Suatu konstrak variabel dikatakan memiliki confirmatory model yang baik apabila memenuhi kriteria goodness of fit (Rosenbaum \& Spears, 2009).

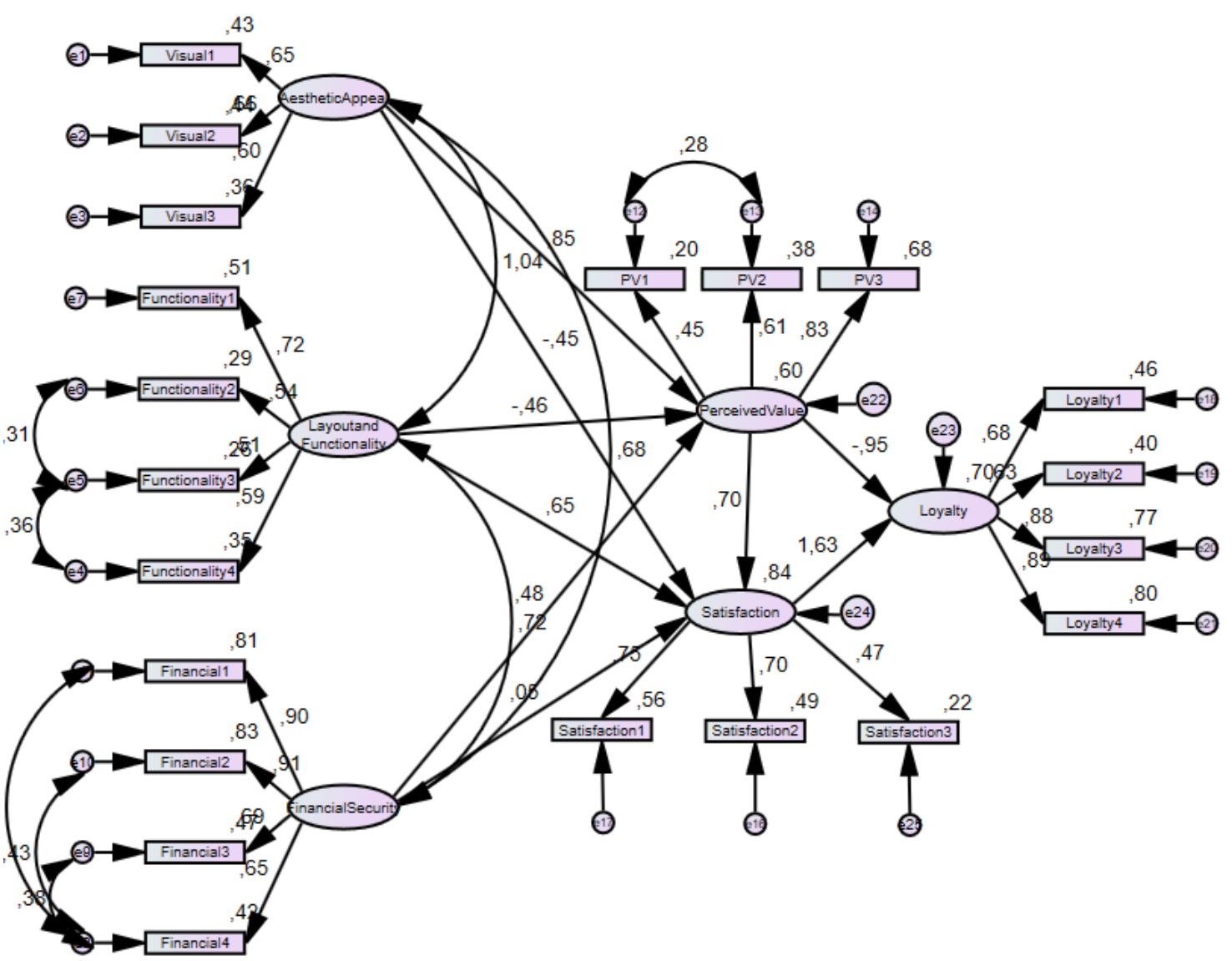

Sumber: Hasil olah data primer (2019).

Gambar 2. Hasil Struktural Model Penelitian

Tabel 3. Hasil Uji Goodnes of Fit pada Model Penelitian

\begin{tabular}{cccc}
\hline Good of Fit Index & Cut-off Value & Hasil Model & Keterangan \\
\hline CMIN/DF & $\leq 2,00$ & 2,019 & Marginal \\
\hline CFI & $\geq 0,95$ & 0,995 & Baik \\
\hline TLI & $\geq 0,95$ & 0,987 & Baik \\
\hline RMSEA & $\leq 0,08$ & 0,069 & Baik \\
\hline GFI & $\geq 0,90$ & 0,934 & Baik \\
\hline AGFI & $\geq 0,90$ & 0,911 & Baik \\
\hline
\end{tabular}

Sumber: Hasil analisis data primer (2019).

Gambar 2 dan Tabel 3 menunjukkan hasil olah data menggunakan SEM dan hasil uji goodness of fit dengan menggunakan nilai cut-off seperti yang disarankan oleh 
Rosenbaum dan Spears (2009). Berdasarkan Tabel 3 tersebut, model yang digunakan dalam penelitian ini telah memenuhi kriteria pengujian, meskipun nilai CMIN/DF berada pada posisi marginal.

Tabel 4. Hasil Uji Hipotesis Pengaruh Langsung

\begin{tabular}{|c|c|c|c|c|c|c|}
\hline Hipotesis & Pengaruh & $\begin{array}{c}\text { Std. } \\
\text { Regression } \\
\text { Weight }\end{array}$ & $\begin{array}{l}\text { Std. } \\
\text { Error }\end{array}$ & $\begin{array}{l}\text { Critical } \\
\text { Ratio }\end{array}$ & $\mathbf{p}$ & Keterangan \\
\hline $\mathrm{H} 1$ & $\begin{array}{l}\text { Perceived Value } \leftarrow \\
\text { Aesthetic Appeal }\end{array}$ & 0,371 & 0,129 & 2,884 & 0,039 & Terdukung \\
\hline $\mathrm{H} 2$ & $\begin{array}{l}\text { Kepuasan Pengguna } \leftarrow \\
\text { Aesthetic Appeal }\end{array}$ & 0,817 & 0,288 & 2,835 & 0,017 & Terdukung \\
\hline $\mathrm{H} 3$ & $\begin{array}{l}\text { Perceived Value } \leftarrow \\
\text { Layout and } \\
\text { Functionality }\end{array}$ & 0,546 & 0,191 & 2,862 & 0,050 & Terdukung \\
\hline $\mathrm{H} 4$ & $\begin{array}{l}\text { Kepuasan Pengguna } \leftarrow \\
\text { Layout and } \\
\text { Functionality }\end{array}$ & 0,448 & 0,169 & 2,649 & 0,043 & Terdukung \\
\hline H5 & $\begin{array}{l}\text { Perceived Value } \leftarrow \\
\text { Financial Security }\end{array}$ & 0,319 & 0,084 & 3,805 & 0,005 & Terdukung \\
\hline H6 & $\begin{array}{l}\text { Kepuasan Pengguna } \leftarrow \\
\text { Financial Security }\end{array}$ & 0,355 & 0,064 & 5,508 & 0,011 & Terdukung \\
\hline $\mathrm{H} 7$ & $\begin{array}{l}\text { Kepuasan Pengguna } \leftarrow \\
\text { Perceived Value }\end{array}$ & 1,088 & 0,379 & 2,870 & 0,004 & Terdukung \\
\hline H8 & $\begin{array}{l}\text { Loyalitas Pengguna } \leftarrow \\
\text { Perceived Value }\end{array}$ & 1,443 & 0,722 & 1,998 & 0,004 & Terdukung \\
\hline H9 & $\begin{array}{l}\text { Loyalitas Pengguna } \leftarrow \\
\text { Kepuasan Pengguna }\end{array}$ & 1,588 & 0,721 & 2,202 & 0,028 & Terdukung \\
\hline
\end{tabular}

Sumber: Hasil analisis data primer (2019).

Pengujian hipotesis pengaruh langsung dilakukan dengan melihat nilai probability (p) yang menghasilkan pengaruh antara variabel eksogen terhadap variabel endogen. Nilai probability yang diharapkan adalah kurang dari $0,05(\alpha=5 \%)$, sehingga hasil tersebut menunjukkan adanya pengaruh signifikan. Hasil pada Tabel 4 tersebut menunjukkan tidak ada nilai $\mathrm{p}$ yang lebih besar daripada 0,05 , sedangkan $\mathrm{H} 3$ memiliki nilai $\mathrm{p}=0,05$. Menurut Rosenbaum dan Spears (2009), pada kondisi $\mathrm{p}=0,05$ hipotesis dianggap terdukung, sehingga seluruh hipotesis yang diajukan dalam penelitian ini terdukung.

\section{Pembahasan}

\section{Persepsi atas Aesthetic Appeal berpengaruh positif pada Perceived Value peng- guna website Shopee}

Hasil uji hipotesis pertama (H1) menunjukkan bahwa persepsi atas aesthetic appeal berpengaruh positif pada perceived value pengguna website Shopee. Hasil analisis menunjukkan pengguna Shopee merasakan nilai positif saat menggunakan website Shopee karena memiliki tampilan visual yang menarik dan mudah dipahami, sehingga pengguna merasa lebih mudah menggunakan websitenya. Hasil ini sesuai dengan hasil penelitian Shun dan Xu (2011). Penelitian tersebut mengungkapkan bahwa aesthetic appeal berpengaruh terhadap nilai yang dirasakan oleh pengguna. Pengguna 
merasakan bahwa tampilan website yang menarik memiliki penilaian positif terhadap website tersebut. Hasil penelitian Wells et al. (2011) juga menunjukkan hal serupa dengan hasil penelitian ini. Wells et al. (2011) menunjukkan bahwa konsumen percaya kepada penjual yang berkualitas yaitu mereka yang mampu berinvestasi pada tampilan visual yang menarik, sehingga tampilan visual dapat berpengaruh pada nilai positif yang dirasakan oleh pengguna terhadap website.

\section{Persepsi atas Aesthetic Appeal berpengaruh positif pada Kepuasan Pengguna website Shopee}

Sesuai dengan hasil uji hipotesis kedua $(\mathrm{H} 2)$ yang telah dijabarkan sebelumnya menunjukkan persepsi tentang aesthetic appeal berpengaruh positif terhadap kepuasan pengguna. Pengguna Shopee merasakan kepuasan ketika ia menggunakan websitenya, karena adanya berbagai sisi hiburan (seperti permainan), sehingga pengguna memiliki pengalaman berbelanja yang menyenangkan di website Shopee. Hasil tersebut menunjukkan bahwa pengguna website Shoppe memberi tanggapan positif terhadap elemen aesthetic appeal pada websitenya. Hasil ini sama dengan penelitian Shun dan Xu (2011) yang menunjukkan bahwa website yang memiliki tampilan menyenangkan akan lebih mudah memberikan kepuasan pada aspek yang lain. Shun dan Xu (2011) juga mengungkapkan bahwa website yang menarik akan lebih cepat membuat pengguna berbelanja dengan menyenangkan. Demikian pula hasil penelitian yang dilakukan oleh Ha dan Stoel (2012) yang mengungkapkan bahwa pengguna membutuhkan sebuah tampilan website yang menyenangkan untuk mendukung penilaian terhadapnya. Tampilan website yang menyenangkan akan membuat pengguna merasa puas berbelanja melalui website tersebut.

\section{Persepsi atas Layout \& Functionality berpengaruh positif pada Perceived Value pengguna website Shopee}

Hasil uji hipotesis ketiga (H3) menjelaskan bahwa persepsi atas layout \& functionality berpengaruh signifikan terhadap perceived value pengguna. Hasil analisis menunjukkan bahwa pengguna Shopee merasakan nilai positif saat ia menggunakan website Shopee, karena tata letak dan fungsi website memungkinkan penggunaan yang lebih mudah dan sangat membantu dalam pencarian produk. Bahkan, pengguna pertama pun dapat menghemat waktu dan mudah menggunakan website Shopee. Hasil ini sesuai dengan penelitian Luo et al. (2012) yang mengungkapkan bahwa tata letak website memainkan peran penting ketika pengguna mencoba menemukan informasi online. Kemudahan akses untuk mendapatkan sebuah informasi akan meningkatkan nilai persepsi pengguna. Demikian pula dengan penelitian Wu et al. (2014) yang mengungkapkan bahwa semakin sedikit usaha yang dilakukan konsumen untuk mencari informasi sebuah produk dalam suatu website, maka semakin tinggi nilai yang dirasakan oleh pengguna tersebut. Informasi yang cukup memadai dan cepat ditemukan akan membentuk penilaian pengguna terhadap brand suatu website.

\section{Persepsi atas Layout \& Functionality berpengaruh positif pada Kepuasan Peng- guna website Shopee}

Hasil uji hipotesis keempat (H4) menyebutkan bahwa persepsi atas Layout \& Functionality berpengaruh positif terhadap kepuasan pengguna. Pengguna Shopee merasakan kepuasan saat menggunakan website Shopee, karena rekomendasi produk yang sesuai kebutuhan dan fungsi kata kunci yang baik, sehingga ia merasa puas saat berbelanja melalui website Shopee. Hal itu ditunjukkan dari hasil analisis yang menun- 
jukkan bahwa pengguna website Shoppe memberi tanggapan positif terhadap indikator tentang fungsi kata kunci yang disediakan oleh Shopee. Hasil ini sesuai dengan penelitian Wang et al. (2001) yang menunjukkan bahwa pemberian informasi tentang rincian produk, pengelompokan produk, dan kata kunci pencarian yang sesuai akan membuat pengguna merasa puas dengan produk yang direkomendasikan oleh website karena sesuai dengan produk yang ia cari. Penelitian Luo et al. (2012) juga mengungkapkan hal yang serupa. Pengkategorian produk merupakan hal yang penting, karena hal itu dapat memberikan kemudahan pencarian, sehingga website dapat memberikan pengalaman berbelanja yang memuaskan. Pengkategorian secara jelas dapat menghindari ketidakcocokan antara produk yang dibeli dengan yang diharapkan oleh pembeli.

\section{Persepsi atas Financial Security berpengaruh positif pada Perceived Value pengguna website Shopee}

Uji hipotesis kelima (H5) menyatakan bahwa persepsi atas financial security berpengaruh positif terhadap perceived value. Sistem pembayaran Shopee yang aman, efisien, dan mudah dilakukan dirasakan positif oleh pengguna. Sistem pembayaran yang mudah dapat menghemat waktu dan memudahkan penggunaan website bagi pengguna. Hasil ini sejalan dengan penelitian Zeithaml et al. (2002) yang mengungkapkan bahwa aspek financial security merupakan aspek penting saat pembelanjaan online sebagai penentu nilai aman dirasakan oleh pengguna website. Ketika website dapat menjamin keamanan pembayaran yang dilakukan oleh pengguna, maka pengguna merasakan nilai lebih suatu website. Hasil penelitian ini juga sesuai dengan penelitian Montoya-Weiss et al. (2003). Dalam penelitiannya, Montoya-Weiss et al. (2003) mengungkapkan bahwa kemudahan metode pembayaran yang ditawarkan oleh sebuah website akan mempengaruhi penilaian yang diberikan oleh penggunanya. Pengguna akan memiliki penilaian positif ketika website menawarkan berbagai pilihan metode pembayaran yang dapat memudahkan saat mereka berbelanja melalui website.

\section{Persepsi atas Financial Security berpengaruh positif pada Kepuasan Pengguna website Shopee}

Sesuai hasil uji hipotesis keenam (H6), persepsi atas financial security berpengaruh positif terhadap kepuasan pengguna. Pengguna Shopee merasakan nilai positif sistem pembayaran Shopee yang aman, efisien, dan mudah dilakukan, seperti yang ditunjukkan oleh hasil analisis data dalam penelitian ini. Pengguna merasa bahwa sistem pembayaran yang mudah dapat memberikan pengalaman yang menyenangkan selama menggunakan website. Hasil ini sesuai dengan penelitian Guo et al. (2012) yang menyatakan bahwa pengguna akan merasa puas ketika website menawarkan berbagai alternatif metode pembayaran. Pengguna akan merasa lebih puas terhadap website yang menyediakan metode pembayaran yang mudah dan efisien. Wang et al. (2001) mengungkapkan hal serupa dalam penelitiannya. Proses transaksi yang jelas dan mudah akan membuat pelanggan merasa puas. Selain itu, Shopee perlu memberikan rincian harga (termasuk ongkos kirim) yang jelas agar dapat meningkatkan kepuasan pelanggan. Pelanggan akan merasa mengeluarkan sedikit usaha untuk melakukan transaksi pembayaran pada website tersebut.

\section{Perceived Value berpengaruh positif pada Kepuasan Pengguna website Shopee}

Melalui uji hipotesis ketujuh (H7), variabel perceived value berpengaruh signifikan terhadap kepuasan pengguna website Shopee. Pengguna Shopee merasakan kepuasan karena mereka merasakan adanya nilai-nilai positif selama menggunakan website- 
nya. Pengguna merasa memerlukan hanya sedikit usaha untuk menggunakan website, serta menghemat waktu dan mudah menggunakan website tersebut. Hasil ini serupa dengan yang diungkapkan oleh $\mathrm{Wu}$ et al. (2014), yaitu semakin positif nilai yang dirasakan pengguna website terhadap elemen e-servicescape, maka semakin tinggi tingkat kepuasan pelanggan tersebut. Pelanggan akan merasa puas ketika mereka merasa sedikit mengeluarkan usaha untuk mendapatkan fungsi optimal e-servicescape sebuah website (Wu et al., 2014). Pentingnya customer perceived value bagi kepuasan pengguna website juga disampaikan oleh Lin dan Sun (2009). Penggunaan konsep customer perceived value tidak hanya menghasilkan pelanggan yang lebih puas, tetapi yang lebih penting lagi adalah efek langsung pada niat dan loyalitas pembelian kembali oleh pelanggan. Dengan kata lain, semakin banyak manfaat yang ditawarkan oleh suatu produk atau layanan melalui website, pelanggan akan semakin puas, sehingga semakin tinggi peluang yang mengarah pada perilaku positif (Lin \& Sun, 2009).

\section{Perceived Value berpengaruh positif pada Loyalitas Pengguna website Shopee}

Hasil uji hipotesis kedelapan (H8) menunjukkan bahwa variabel perceived value berpengaruh signifikan terhadap loyalitas pengguna. Hal ini sejalan dengan hasil analisis yang menyatakan bahwa pengguna Shopee memiliki loyalitas karena mereka merasakan adanya nilai-nilai positif selama menggunakan websitenya. Pengguna merasa memerlukan usaha sedikit untuk menggunakan website serta menghemat waktu dan kemudahan penggunaan websitenya. Karena pengalaman positif ini, pengguna berkehendak merekomendasikan website Shopee kepada pihak lain, serta mereka selalu menjadikan website Shopee sebagai pilihan utama saat berniat melakukan pembelian. Hasil ini sama dengan yang diungkapkan Wang et al. (2001). Dalam penelitian tersebut, mereka mengungkapkan bahwa ketika pelanggan memberikan penilaian positif terhadap e-servicescape dan mereka merasa mendapatkan banyak keuntungan dengan mengeluarkan tingkat usaha yang tidak tinggi, maka pelanggan akan kembali menggunakan website tersebut dan menjadikannya sebagai pilihan utama (Wang et al., 2001). Sama halnya dengan hasil penelitian Tankovic dan Benazic (2018) yang menyatakan bahwa ketika pengguna merasa suatu e-commerce memberikan keuntungan ekonomis, menghemat waktu, dan aktifitas jual beli dapat dilakukan dengan mudah tanpa usaha yang besar, maka kondisi itu akan mendorong mereka untuk merekomendasikannya kepada orang lain. Dengan demikian, perceived value sebuah e-commerce dapat mempengaruhi loyalitas pengguna.

\section{Kepuasan Pengguna berpengaruh positif pada Loyalitas Pengguna website Shopee}

Seperti pengaruh variabel perceived value terhadap loyalitas pengguna, variabel kepuasan pengguna juga berpengaruh signifikan terhadap loyalitas pengguna Shopee. Berdasarkan analisis data, pengguna Shopee memiliki loyalitas karena mereka merasakan kepuasan selama menggunakan websitenya. Pengguna merasa puas dengan pengalaman dan pelayanan yang diperolehnya selama menggunakan website. Karena pengalaman positif tersebut, pengguna Shopee berkehendak merekomendasikan website Shopee kepada pihak lain, dan mereka selalu menjadikan website Shopee sebagai pilihan utama saat berniat melakukan pembelian. Ha dan Stoel (2012) juga mengungkapkan hal serupa pada hasil penelitiannya, yaitu pengguna website merasa puas terhadap sebuah $e$ commerce karena tampilan visualnya, berbagai informasi yang disediakannya, dan juga banyaknya alternatif pembayaran pada e-commerce tersebut, sehingga hal itu mendo- 
rong mereka untuk merekomendasikannya kepada orang lain. Dengan demikian, kepuasan pelanggan atas layanan e-commerce dapat mempengaruhi loyalitas pengguna website. Penelitian Guo et al. (2012) mengungkapkan hal yang sama, yaitu seluruh elemen e-servicescape saling terkait satu sama lain untuk menciptakan kepuasan pengguna website. Diawali dari tampilan visual yang menarik saat pertama kali membuka website, tata letaknya yang memudahkan untuk digunakan, kata kunci pencarian sesuai dengan produk yang dicari, dan sistem pembayaran yang aman dan efisien akan memberikan kepuasan optimal bagi pengguna website. Dari kepuasan pengguna tersebut terbentuklah loyalitas mereka untuk melakukan transaksi ulang pada website tersebut setiap kali pengguna berniat membeli produk.

\section{KESIMPULAN DAN SARAN}

Dari hasil analisis dalam penelitian ini, seluruh elemen e-servicescape yang diteliti berpengaruh terhadap perceived value dan kepuasan pengguna website Shopee. Shopee memiliki aspek financial security sebagai aspek e-servicescape yang dinilai oleh pengguna website sebagai aspek yang terbaik. Pengguna website Shopee sepakat bahwa prosedur pembayaran Shopee cukup efisien dan mudah digunakan. Untuk itu, Shopee perlu mempertahankan kinerja financial security agar semakin memberikan kemudahan pada prosedur pembayaran. Hal itu dapat dilakukan melalui penambahan cara pembayaran, seperti bekerja sama dengan penyedia jasa aplikasi $e$-wallet. Shopee juga dapat menambah jumlah bank yang bekerja sama dengannya.

Pada aspek e-servicescape yang masih perlu mendapat perhatian untuk diperbaiki adalah aspek Layout \& Functionality. Aspek navigasi mendapatkan penilaian terendah dari berbagai aspek e-serviscape yang diteliti. Untuk maksud tersebut, Shopee perlu memperhatikan alur navigasi agar pengguna lebih mudah menggunakannya. Penggunaan tombol yang lebih jelas akan memudahkan pengguna untuk berpindah halaman. Pengaturan pada "halaman promo," halaman "check-out," halaman "chat," halaman "ShopeePay," dan halaman "Favorit Saya" dapat didisain ulang agar lebih rapi dan memudahkan pengguna untuk melakukan akses. Peningkatan terhadap relevansi antara kata kunci dengan produk yang ditampilkan juga perlu dibenahi agar sesuai dengan produk yang diharapkan pengguna.

Hail penelitian ini menunjukkan bahwa semakin positif persepsi pengguna terhadap elemen e-servicescape, maka semakin positif pula perceived value yang dirasakan mereka. Hal ini menandakan bahwa Shopee perlu meningkatkan kinerja e-servicescape, sehingga pengguna akan semakin merasakan kemudahan menggunakan website Shopee. Dengan demikian, pengguna akan merasa puas dengan website Shopee. Hasil analisis menunjukkan bahwa pengguna website sudah cukup merasakan nilai positif website Shopee. Secara keseluruhan, pengguna merasa website Shopee mudah digunakan dan sangat menghemat waktu. Karena itu, pengguna merasa puas dan menyenangkan berbelanja melalui website Shopee.

Shopee harus mampu mempertahankan kinerja yang lebih baik dan meningkatkannya melalui inovasi-inovasi baru. Hal tersebut tidak terlepas dari usaha untuk meningkatkan loyalitas pengguna website Shopee. Hasil analisis data menunjukkan bahwa pengguna cukup memiliki loyalitas karena selalu memilih website Shopee sebagai pilihan pertama saat berniat membeli produk secara online dan jarang mempertimbangkan untuk beralih ke marketplace website lainnya. Namun, tingkat pembelian 
melalui website Shopee masih cukup rendah. Hal ini terlihat dari sebagian besar pengguna website Shopee hanya membeli satu hingga tiga kali saja melalui website Shopee dalam enam bulan terakhir. Kondisi tersebut memerlukan upaya untuk meningkatkan kesesuaian kata kunci agar pengguna dapat menemukan lebih banyak produk yang diinginkan dalam waktu singkat. Dengan demikian, pengguna dapat lebih sering mengakses website Shopee untuk berbelanja kebutuhannya.

\section{DAFTAR REFERENSI}

Adiwijaya, M., Thomas, S. K., Agustinus, N., Endo, W. K. (2016). The Descriptive Analysis of Aesthetic Appeal, Layout and Functionality, and Financial Security: Case Study for The Indonesian E-Commerce. International Conference on Internet Studies, Osaka.

Baker, J. (1986). The Role of the Environment in Marketing Services: The Consumer Perspective. The Services Challenge: Integrating for Competitive Advantage. 7984.

Bian, H. (2011). Structural Equation Modelling with AMOS II. http://core.ecu.edu/ofe/ statisticsresearch/SEM\%20with\%20AMOS\%20II.pdf

Dailey, L. (2004). Navigational Web Atmospherics: Explaining the Influence of Restrictive Navigation Cues. Journal of Business Research, 57, 795-803.

Eroglu, S.A., Machleit, K. A., Davis, L. M. (2001). Atmospheric Qualities of Online Retailing: A Conceptual Model and Implications. Journal of Business Research, 50, 177-184.

Friedman, B., Khan, P. Jr., \& Howe, D. (2000). Trust Online. Communication of the ACM, 43, 34-40. DOI: $10.1145 / 355112.355120$.

Guo, X., Ling, K., \& Liu, M. (2012). Evaluating Factors Influencing Consumer Satisfaction Towards Online Shopping in China. Asian Social Science, 8. DOI: 10.5539/ass.v8n13 p40.

Ha, S. \& Stoel, L. (2012). Online Apparel Retailing: Roles of E-shopping Quality and Experiential E-shopping Motives. Journal of Service Management, 23(2), 197215.

Harris, L. C. \& Goode, M. M. (2010). Online Servicescapes, Trust, and Purchase Intentions. Journal of Services Marketing, 24(3), 230-243.

Hoffman, D. L. \& Novak, T. P. (1996). Marketing in Hypermedia Computer-Mediated Environments: Conceptual Foundations. Journal of Marketing, 60, 50-68.

iPrice Group (2018). Peta E-Commerce Indonesia. https://iprice.co.id/insights/mapofecommerce/.

Kotler, P. \& Keller, K. L. (2016). Marketing Management. 15th Global Edition. Boston: Pearson Education, Inc.

Lin, G. \& Sun, C. C. (2009). Factors Influencing Satisfaction and Loyalty in Online Shopping: An Integrated Model. Online Information Review, 33, 458-475.

Luo J., Sulin, B., \& Han, Z. (2012). The Effectiveness of Online Shopping Characteristics and Well-Designed Websites on Satisfaction. MIS Quarterly, 36(4), 11311144 
Maxwell, J. A. (1996). Qualitative Research Design: An Interactive Approach. Applied Social Research Methods Series Vol 41. Sage Publications, Inc.

Montoya-Weiss, M., Voss, G. B., \& Grewal, D. (2003), Determinants of Online Channel Use and Overall Satisfaction With a Relational, Multichannel Service Provider. Journal of the Academy of Marketing Science, 31(4), 448-458.

Rajani, R. \& Rosenberg, D. (1999). Usable? or Not? Factors Affecting the Usability of Websites. CMC Mag, 1-5(January).

Rosenbaum, M. \& Spears, D. (2009). Using Group Comparisons in AMOS to Explore Shopping as a Travel Driver. International Journal of Culture, Tourism, and Hospitality Research, 3, 313-325.

Setyowati, D. (2018). Transaksi Shopee Mencapai Rp39,4 Triliun Sepanjang Kuartal III 2018. https://katadata.co.id/berita/2018/11/28/transaksi-shopee-mencapai-rp-394triliun-sepanjang-kuartal-iii-2018.

Shun, C. \& Xu, Y. (2011). Designing Not Just for Pleasure: Effects of Web Site Aesthetics on Consumer Shopping Value. International Journal of Electronic Commerce, 15.

SimiliarWeb. (2018). Shopee Performance Analysis. https://pro.similarweb.com/\#/work space/hook.

Tankovic, A. C. \& Benazic, D. (2018). The Perception of E-servicescape and Its Influence on Perceived E-shopping Value and Customer Loyalty. Online Information Review, 42(7), 1124-1145.

Wang, Y. S., Tang, T. I., \& Tang, J. T. E. (2001). An Instrument for Measuring Customer Satisfaction toward Websites that Market Digital Products and Services. Journal of Electronic Commerce Research, 2(3), 89-102.

Wells, J. D., Valacich, J. S., \& Hess, T. J. (2011). What Signal are You Sending? How Website Quality Influences Perceptions of Product Quality and Purchase Intentions. MIS Quarterly, 35(2), 373-396.

Westbrook, R. A. (1987). Product/Consumption-Based Affective Responses and Postpurchase Processes. Journal of Marketing Research, 24(3), 258-270.

Wu, L.Y., Chen, K.Y., Chen, P.Y., \& Cheng, S.L. (2014), Perceived Value, Transaction Cost, and Repurchase-Intention in Online Shopping: A Relational Exchange Perspective. Journal of Business Research, 67(1), 2768-2776.

Yang, Z. \& Peterson, R. T. (2004). Customer Perceived Value, Customer Satisfaction, and Loyalty: The Role of Switching Costs. Psychology \& Marketing, 21(10), 799822.

Zeithaml, V. A., Parasuraman, A., \& Malhotra, A. (2002), Service Quality Delivery Through Web Sites: A Critical Review of Extant Knowledge. Journal of the Academy of Marketing Science, 30(4), 362-75.

Zikmund, W.G, Babin, B.J., Carr, J.C, \& Griffin, M. (2013). Business Research Method. 9th Global Edition. South-Western: Cengage Learning. 